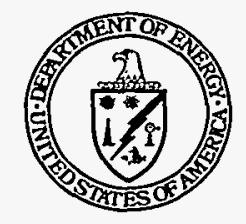

\title{
Disposal Requirements for PCB Waste
}

BACKGROUND:

Polychlorinated biphenyls (PCBs) are a class of organic chemicals that had become widely used in industrial applications due to their practical physical and chemical properties. Historical uses of PCBs include dielectric fluids (used in utility transformers, capacitors, etc.), hydraulic fluids, and other applications requiring stable, fire-retardant materials. Due to findings that PCBs may cause adverse health effects and due to their persistence and accumulation in the environment, the Toxic Substances Control Act (TSCA), enacted on October 11, 1976, banned the manufacture of PCBs after 1978 [Section 6(e)]. The first PCB regulations, promulgated at 40 CFR Part 761, were finalized on February 17, 1978. These PCB regulations include requirements specifying disposal methods and marking (labeling) procedures, and controlling PCB use. To assist the Department of Energy (DOE) in its efforts to comply with the TSCA statute and implementing regulations, the Office of Environmental Guidance has prepared the document "Guidance on the Management of Polychlorinated BiphenyIs (PCBs)." That document explains the requirements specified in the statute and regulations for managing PCBs including PCB use, storage, transport, and disposal.

PCB materials that are no longer in use and have been declared a waste must be disposed of according to the requirements found at $40 \mathrm{CFR} 761.60$. These requirements establish disposal options for a multitude of PCB materials including soil and debris, liquid PCBs, sludges and slurries, containers, transformers, capacitors, hydraulic machines, and other electrical equipment. This Information Brief supplements the PCB guidance document by responding to common questions concerning disposal requirements for PCBs. It is one of a series of Information Briefs pertinent to PCB management issues.

STATUTE: Toxic Substances Control Act of 1976 (TSCA)

REGULATION: 40 CFR Part 761

REFERENCES:

1. "Guidance on the Management of Polychlorinated Biphenyls (PCBs), "Environmental Guidance Manual, DOE Office of Environmental Guidance, RCRACERCLA Division (EH-231), DOE/EH-0350, June 1993.

2. "Disposal Methods for PCBs in Sludge," TSCA Compliance Program Policy No. 6-PCB-4, Environmental Protection Agency, August 13, 1985.

3. "Determination Regarding the Scope of 40 CFR $761.60(a)(4)$," Environmental Protection Agency, November 13, 1989.

4. "PCB Storage Requirements," EH-231 TSCA Information Brief, EH-231-060/1294, Office of Environmental Guidance, RCRA/CERCLA Division, December 1994.

5. Rollins Environmental Services (NJ) Inc. v. U.S. Environmental Protection Agency, U.S. Court of Appeals for the District of Columbia Circuit, Case No. 90-1508, Petition for Review of a Final Decision of the Environmental Protection Agency, July 5, 1991.

\section{When should disposal requirements for PCBs and PCB wastes be considered?}

The TSCA PCB disposal regulations at $40 \mathrm{CFR} 761.60$ should be considered when PCBs and PCB Items with a PCB concentration of $\geq 50 \mathrm{ppm}$ are no longer in use and are declared to be a waste. In certain circumstances, wastes with a PCB concentration of $<50 \mathrm{ppm}$ must also meet the disposal requirements of $40 \mathrm{CFR} 761$ (please refer to the next question for a further discussion). Once determined to be no longer "in service," $\mathrm{PCB}$ wastes with a PCB concentration $\geq 50 \mathrm{ppm}$ must be disposed of in a TSCA incinerator, TSCA chemical waste landfill, or by an Environmental Protection Agency (EPA)-approved alternative method within 1 year. PCB Items in use are not subject to TSCA disposal regulations until declared a waste. Furthermore, there are no regulations pertaining to a maximum amount of time PCB Items may be stored for use or reuse as long as the items are in useful condition and a future use has been identified. However, PCB Items that are no longer fit for use (e.g., leaking capacitors) must be taken out of service and declared a waste at that time. PCBs and PCB Items stored for use or reuse are not required to be stored in a PCB storage facility except for PCB dielectric fluid used to service PCB Transformers, which must be stored in a facility that meets the requirements of 40 CFR 761.65(b) (see reference \#4).

Are there any disposal requirements for PCB wastes with a concentration $<50$ ppm?

Wastes containing $<50 \mathrm{ppm}$ PCB must be disposed of in a responsible manner; that is, they may be disposed of in a municipal waste landfill or equivalent. When disposing of any PCB waste material, potential Comprehensive Environmental Response, Compensation, and Liability Act (CERCLA) liability should be a consideration. It is important to note that PCBs and PCB Items with a concentration $<50$ ppm may not be disposed of by using the PCB material in any way prohibited under 40 CFR $761.20(\mathrm{~d})$, such as road oiling, general dust control, use as a pesticide or herbicide

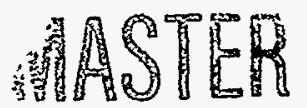


carrier, or as a rust preventative on pipes. In addition, although burning of waste oil containing any quantifiable level of PCBs (i.e., $\geq 2 \mathrm{ppm}$ but $\leq 50 \mathrm{ppm}$ ) for energy recovery is permitted, such burning is subject to the TSCA requirements at 40 CFR 761.20(e).

Materials containing $<50 \mathrm{ppm} \mathrm{PCB}$ are also subject to requirements under the Anti-dilution Rule [40 CFR 761.1(b)], which states that it is prohibited to dilute $\mathrm{PCB}$ materials at a concentration of $\geq 50 \mathrm{ppm}$ with PCB-free materials or lowconcentration PCBs in order to reduce the concentration in the resultant mixture below $50 \mathrm{ppm}$. This prohibition applies whether the dilution was deliberate, unintentional, or accidental. For example, solvents that have been used to flush a PCB Transformer (i.e., $\geq 500$ ppm PCB) must be disposed of as $\mathrm{PCB}$ liquid waste containing $\geq 500 \mathrm{ppm}$ PCB (e.g., in a TSCA incinerator) even though the actual concentration of PCBs in the solvent may be lower. Another example is soil that becomes contaminated from a leaking capacitor; even though some of the soil may contain $<50 \mathrm{ppm}$ PCB, it still must be disposed of as if it contained the PCB concentration of the PCB capacitor. As a result of the Anti-dilution Rule, some materials that contain PCBs at concentrations $<50$ ppm are considered to have the original concentration of $\mathrm{PCBs}$ and must be disposed of in accordance with the TSCA disposal regulations.

\section{What are the disposal options for PCBs?}

In general, the TSCA regulations identify three principal disposal methods for PCBs: (1) incineration in a TSCA-approved facility, (2) disposal in a TSCA-approved chemical waste landfill, and (3) disposal by an EPA-approved alternative method. Although all of the disposal requirements cannot be discussed in detail in this Information Brief, those for the most common types of $\mathrm{PCB}$ wastes are summarized below.

\section{Solids}

Soil and debris (trash, lumber, rags, etc.) or any non-liquid waste contaminated by $\mathrm{PCB}$ at a concentration $\geq 50 \mathrm{ppm}$ may be disposed of in a TSCA incinerator, in a TSCA chemical waste landfill, or by an EPA-approved alternative method.

\section{口 Liquids}

Liquid PCBs at a concentration $\geq 500$ ppm must be incinerated or be destroyed using an EPA-approved alternative method.

Liquid PCBs $<500$ ppm may be disposed of in a TSCA chemical waste landfill provided that the waste is not ignitable and is stabilized to a non-flowing consistency. Liquid PCBs at concentrations $<500 \mathrm{ppm}$ may also be disposed of in an EPA-approved high-efficiency boiler or in a TSCA incinerator.

\section{Sludges and Slurries}

The disposal of industrial sludges and slurries containing PCBs at concentrations $\geq 50 \mathrm{ppm}$ is not specifically regulated at 40 CFR Part 761. However, EPA has issued two policy statements (see References \#2 and \#3) in which the agency established requirements for disposal of industrial sludges and slurries according to $\mathrm{PCB}$ concentration. That is, industrial sludges and slurries $\geq 500 \mathrm{ppm}$ should be disposed of in a TSCA incinerator or by an EPAapproved alternative method, and industrial sludges and slurries $<500 \mathrm{ppm}$ should be disposed of in a TSCA incinerator or TSCA chemical waste landfill, or by an EPA-approved alternative method. Alternatively, the solid and liquid phases of industrial sludges and slurries with a PCB concentration $<500$ ppm may be separated (processed) and each phase may be disposed of according to the TSCA disposal regulations for liquid and non-liquid PCBs, respectively. In this case, the Anti-dilution Rule would apply, and TSCA would require that the liquid and nonliquid phases of the sludge be disposed of according to the original PCB concentration of the material. Processing may not be used to avoid the high-temperature incineration requirements that apply to $\mathrm{PCB}$ sludges $\geq 500 \mathrm{ppm}$ PCB.

\section{Electrical and Other Equipment Containing PCBs}

PCB Transformers that contain $\geq 500$ ppm PCB may be disposed of in a TSCA chemical waste landfill if they are first drained of dielectric fluid and then flushed with an appropriate solvent. (Solvents used to flush PCB Transformers should be carefully chosen to avoid or minimize the generation of PCB-contaminated hazardous wastes subject to the Resource Conservation and Recovery Act [RCRA].) PCB-contaminated transformers (i.e., containing PCBs at concentrations $50-499 \mathrm{ppm}$ ) may be disposed of in a chemical waste landfill if they have been drained of free-flowing liquid PCBs. Under the provisions at $40 \mathrm{CFR}$ 761.3 , salvaging and smelting may be considered an acceptable method of disposal for PCB-contaminated transformer carcasses. Non-PCB transformers (i.e., $<50 \mathrm{ppm}$ $\mathrm{PCB}$ ) are not regulated for disposal, meaning that they do not have to be incinerated or disposed of in a TSCAapproved landfill, or by an EPA-approved alternative method. However, they must be disposed of in a responsible manner. Dielectric fluid from non-PCB transformers is not regulated for disposal provided that the fluid is not used in any way prohibited under 40 CFR 761.20. It is important to note that several States have banned the disposal of used oil in municipal landfills. Facilities should check with the appropriate State agency when disposing of dielectric fluid with PCB concentrations $<50 \mathrm{ppm}$ to ensure that the facility is not in violation of any State regulations.

PCB Capacitors that contain 3 or more pounds of dielectric fluid with a $P C B$ concentration $\geq 50 \mathrm{ppm}$ but $<500 \mathrm{ppm}$ must be disposed of in a TSCA incinerator or TSCA chemical waste landfill, or by an EPA-approved alternative method. Capacitors containing $\geq 3$ pounds of dielectric fluid with a PCB concentration $\geq 500$ ppm must be disposed of by incineration. PCB Small Capacitors (i.e., containing less than 3 pounds of dielectric fluid) may also be disposed of as municipal solid waste in small quantities. In general, "small quantities" has been interpreted to be five small capacitors; however, facilities should verify that the State or the EPA Regional Office has not established 


\section{DISCLAIMER}

This report was prepared as an account of work sponsored by an agency of the United States Government. Neither the United States Government nor any agency thereof, nor any of their employees, make any warranty, express or implied, or assumes any legal liability or responsibility for the accuracy, completeness, or usefulness of any information, apparatus, product, or process disclosed, or represents that its use would not infringe privately owned rights. Reference herein to any specific commercial product, process, or service by trade name, trademark, manufacturer, or otherwise does not necessarily constitute or imply its endorsement, recommendation, or favoring by the United States Government or any agency thereof. The views and opinions of authors expressed herein do not necessarily state or reflect those of the United States Government or any agency thereof. 


\section{DISCLAIMER}

Portions of this document may be illegible in electronic image products. Images are produced from the best available original document. 
more stringent disposal limits. To avoid potential CERCLA liability, more protective disposal options, such as disposal in a RCRA permitted landfill, should be considered.

Other PCB-contaminated electrical equipment (e.g., electric motors, switches, voltage regulators, etc.) with a PCB concentration $\geq 50 \mathrm{ppm}$ but $<500 \mathrm{ppm}$ must be drained of all free-flowing liquid before disposal. The drained electrical equipment may then be disposed of in a municipal landfill. The resultant PCB-contaminated liquid must be disposed of in a TSCA incinerator or chemical waste landfill, or by an alternative disposal method. Salvaging of electrical equipment with a PCB concentration $<500 \mathrm{ppm}$ is a permissible means of disposal for drained electrical equipment, provided that the salvaging terminates the useful life of the equipment. Salvaging that consists of disassembling drained PCB equipment to obtain parts intended for reuse is prohibited.

TSCA allowsPCB hydraulic machines to be disposed of in a municipal solid waste landfill provided that they have been drained of all free-flowing liquids. In addition, hydraulic machines that contained PCBs at a concentration $\geq 1,000 \mathrm{ppm}$ must be flushed with a solvent prior to disposal.

PCB Equipment is defined as any manufactured item, excluding PCB containers, that has component parts containing PCBs (e.g., PCB small capacitors). Examples include microwave ovens, fluorescent light ballasts and fixtures, and other electronic equipment. PCB Equipment may be disposed of as municipal solid waste; however, as with PCB small capacitors, potential CERCLA liability should be considered prior to disposal.

The disposal requirements for other PCB Items, such as bushings, depend on the PCB concentration of the item. If the PCB concentration is $<500 \mathrm{ppm}$, the article may be drained and the resulting carcass may be disposed of as municipal solid waste, provided that the drained liquid is disposed of according to its PCB concentration. If the PCB concentration is $\geq 500 \mathrm{ppm}$, the article must be disposed of in a TSCA incinerator or chemical waste landfill, or by an EPA-approved alternative method.

\section{Containers}

PCB containers may be disposed of in a municipal solid waste landfill or industrial landfill if the PCB concentration is $\geq 50$ but $<500$ ppm and all free-flowing PCBs have been drained from the container. If the PCB concentration is $\geq 500 \mathrm{ppm}$, the container may be disposed of by either incineration at a TSCA-approved facility or drained of all free-flowing PCBs and disposed of in a TSCA chemical waste landfill. Containers with a PCB concentration $\geq 500 \mathrm{ppm}$ may also be decontaminated with solvents and reused as PCB containers. TSCA requirements for decontaminating $\mathrm{PCB}$ containers are found at 40 CFR 761.79.
Is PCB disposal in a chemical waste landfill subject to the RCRA land disposal restrictions (LDRs)?

In some cases, yes. Liquid hazardous wastes (i.e., RCRA listed or characteristic hazardous wastes) that contain PCBs at concentrations $\geq 50$ ppm are California List wastes subject to the RCRALDRs codified at 40 CFR Part 268. PCB-containing wastes must be mixed with, or otherwise contained in, RCRA hazardous wastes (such as a listed solvent) to be subject to the LDR requirement. PCB fluid by itself is not listed as hazardous waste under RCRA. Moreover, PCB-containing dielectric fluids regulated under TSCA that are hazardous only because they exhibit the RCRA Toxicity Characteristic (TC) are exempted from RCRA regulation, including the LDRs, by 40 CFR 261.8. PCBs are also Halogenated Organic Compounds (HOCs). If the total concentration of HOCs in either a liquid or non-liquid hazardous waste is $\geq 1000 \mathrm{mg} / \mathrm{kg}$, the waste is subject to the LDRs, even if the concentration of PCBs is $<50 \mathrm{ppm}$. Other types of PCBs and PCB Items are not subject to the RCRA LDRs.

\section{When are solvents used in the PCB disposal process? Are there any provisions that govern the disposal of solvents used to decontaminate equipment and PCB containers?}

Kerosene, xylene, toluene, and other solvents in which PCBs are readily soluble are used to flush PCBs from transformers that contain PCBs at concentrations $\geq 500 \mathrm{ppm}$ and from hydraulic machines that contain PCBs at concentrations $\geq 1,000 \mathrm{ppm}$ before such equipment may be disposed of in a landfill. In addition, solvents are also used to decontaminate PCB containers. Solvents used to decontaminate containers may be reused for the same purpose until the concentration of PCBs in the solvent reaches $50 \mathrm{ppm}$ PCB. For the purpose of reusing solvents, the PCB concentration should be measured on the basis of the actual concentrations of PCBs in the solvent (see reference \#5). However, once the solvent is declared' a waste (regardless of the actual PCB concentration), the solvent must be managed and disposed of as if it contained the highest PCB concentration of any PCB or PCB Item with which it came into contact. Another consideration is that many of the solvents used to decontaminate containers may also be RCRA hazardous wastes. If used for PCB decontamination, these waste solvents must be managed according to both RCRA and TSCA.
Questions of policy or questions requiring policy decisions will not be addressed in EH-231 Information Briefs unless that policy has already been established through appropriate documentation. Please refer any questions concerning the subject material covered in this Information Brief to Carolyn Thompson Walder, RCRA/CERCLA Division, EH-231, (202) 586-8248.

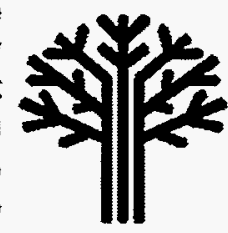


Post Office, if unable to deliver please return to:

Gabrielle Santore

Environmental Compliance Group

Building 800 TPK, MS-6482

Oak Ridge National Laboratory

Oak Ridge, TN 37831-6482

ADDRESS CORRECTION REQUESTED 